\title{
RESEARCH
}

\section{A Second Locus for Hereditary Hemorrhagic Telangiectasia Maps to Chromosome 12}

\author{
David W. Johnson, ${ }^{1}$ Jonathan N. Berg, ${ }^{2}$ Carol J. Gallione, ${ }^{1}$ \\ Kimberly A. McAllister, ${ }^{1}$ Jon P. Warner, ${ }^{2}$ Elizabeth A. Helmbold, ${ }^{3}$ \\ Dorene S. Markel, ${ }^{3}$ Charles E. Jackson, ${ }^{3,4}$ Mary E.M. Porteous, ${ }^{2}$ \\ and Douglas A. Marchuk ${ }^{1,5}$
}

'Department of Genetics, Duke University Medical Center, Durham, North Carolina 27710; ${ }^{2}$ Department of Human Genetics, University of Edinburgh, Western General Hospital, Edinburgh, EH4 2XU, United Kingdom; ${ }^{3}$ Family Studies Core, Human Genome Center, University of Michigan Medical Center, Ann Arbor, Michigan 48109; ${ }^{4}$ Division of Clinical and Molecular Genetics, Henry Ford Hospital,

Detroit, Michigan 48202

Hereditary hemorrhagic telangiectasia (HHT) or Osler-Rendu-Weber (ORW) disease is an autosomal dominant vascular dysplasia. Initial linkage studies identified an ORW gene localized to 9q33-q34 but with some families clearly excluding this region. A probable correlation in clinical phenotype between the 9q3-linked families and unlinked families was described with a significantly lower incidence of pulmonary arteriovenous malformations observed in the unlinked families. In this study we examined four unrelated ORW families for which linkage to chromosome 9q33-q34 has been previously excluded. Linkage was established for all four families to markers on chromosome 12, with a combined maximum lod score of 10.77 $(\theta=0.04)$ with D12S339. Mapping of crossovers using haplotype analysis indicated that the candidate region lies in an 11-cM interval between D12S345 and D12S339, in the pericentromeric region of chromosome 12. A map location for a second ORW locus is thus established that exhibits a significantly reduced incidence of pulmonary involvement.

Hereditary hemorrhagic telangiectasia (HHT) or Osler-Rendu-Weber (ORW) disease is an autosomal dominant multisystemic vascular dysplasia. The three primary types of angiodysplasia exhibited are telangiectases (mucosal, dermal, and visceral), arterial venous malformations (AVMs, particularly pulmonary, cerebral, and hepatic), and aneurysms. Penetrance is age dependent but is considered nearly complete by age 40 (Plauchu et al. 1989; Porteous et al. 1992).

The most common clinical feature of ORW is recurrent epistaxis from vascular lesions in the nasal epithelium, which affects $\sim 90 \%$ of ORW patients (Aassar et al. 1991). Cutaneous telangiectases are seen in $\sim 70 \%$ of affected individuals (Brant et al. 1989; Plauchu et al. 1989). Gastrointestinal bleeding occurs in $\sim 20 \%$ of ORW patients (Reilly and Nostrant 1984; Vase and Grove 1986). Pulmonary arteriovenous malformations

${ }^{5}$ Corresponding author.

E-MAIL marcho04@mc.duke.edu; FAX (919) 684-2790.
(PAVMs) occur in $-20 \%$ of ORW patients (Dines et al. 1974) and are associated with serious complications including stroke and brain abscess (White and Pollak 1994). Neurologic manifestations include cerebral arteriovenous malformation, aneurysm, and migraine headache (Willinsky et al. 1990).

Incidence rates have been calculated for the spectrum of symptoms in a number of retrospective and prospective studies (Reilly and Nostrant 1984; Peery 1987; Plauchu et al. 1989; Porteous et al. 1992). Great variability of expression and severity is seen even among members of the same family, indicating that factors in addition to the inherited germ-line mutation contribute to the individual's phenotype. Until recently it was unclear whether all families present the entire spectrum of clinical features. Differences might be attributable to either allelic or locus heterogeneity.

Genetic linkage for some ORW families was established with markers on 9q3 (McDonald et al. 1994; Shovlin et al. 1994). This locus (ORW1) was 


\section{JOHNSON ET AL.}

subsequently shown to be the endoglin gene that encodes a transforming growth factor- $\beta$ (TGF- $\beta$ )binding protein of endothelial cells (McAllister et al. 1994b). Locus heterogeneity was indicated by families that excluded linkage to this region (Heutink et al. 1994; McAllister et al. 1994a; Porteous et al. 1994; Shovlin et al. 1994). Several reports (Heutink et al. 1994; McAllister et al. 1994a; Porteous et al. 1994) have documented a significantly lower incidence (in some cases, an absence) of PAVMs in non-9q-linked families when compared to 9q-linked families (ORW1). In this report we show that at least some of the genetic and clinical heterogeneity can be explained by a second ORW locus mapping to chromosome 12 .

\section{RESULTS}

Our approach to establish genetic linkage with these families included a candidate gene approach, based on the known map positions of $\sim 20$ growth factors (and their receptors), mitogenic or growth inhibitory for endothelial cells. In addition to these loci, members of the TGF- $\beta$ receptor superfamily, including the activin receptors and activin receptor-like kinases, were considered candidate genes based on the identification of endoglin, a TGF- $\beta$-binding protein, as the gene for ORW1 (McAllister et al. 1994b).

Linkage analysis revealed that the disease gene in four families (Fig. 1) is linked to markers mapping to the pericentromeric region of chromosome 12. The pairwise lod scores between the disease gene and these markers are given in Table 1. Markers D12S85 and D12S339 showed the highest maximum combined lod scores of 9.06 $(\theta=0)$ and $10.77(\theta=0.04)$, respectively. Marker informativity varied considerably among the four families, causing large differences in lod scores for closely spaced markers. For example, in family 67 , marker D12S368 showed a much lower lod score (maximum 0.21 at $\theta=0.21$ ) than marker D12S339 (maximum 3.94 at $\theta=0.05$ ) which is only $3 \mathrm{~cm}$ distal, owing primarily to uninformative genotypes for key affected parents 67-III-10 and 67-III-19. Each family showed highly positive lod scores with at least one of the markers in this region (Table 1).

Informative recombinant individuals were identified to define more precisely the candidate interval. Haplotypes were determined across a 37-cM interval for each family, but crossovers were scored only from affected individuals, be- cause of potential nonpenetrance of unaffected members. There were no unambiguous crossovers in the disease haplotypes in families 2 and 17. Affected individuals from two families (33IV-1 and 67-IV-5) showed crossovers between markers D12S310 and D12S333 (Fig. 2). An affected individual in family 67 (67-IV-2) showed a crossover between D12S345 and D12S85. These place the disease locus in the region between D12S345 and 12qter. One affected individual in family 33 (33-III-3; Fig. 1) showed a crossover between markers D12S339 and D12S85 that provided the distal boundary for the disease locus. The candidate interval is thus bordered by D12S345 and D12S339, an interval of $11 \mathrm{~cm}$ (Fig. 2).

Several individuals diagnosed as unaffected (17-IV-3, age 20; 33-III-5, age 31; 33-III-9, age 27; 67-III-2, age 45; 67-IV-7, age 40; 67-IV-10, age 34; and 67-IV-11, age 49) showed the disease haplotype through most or all of the region, including the entire 11-cm candidate interval. These may represent complex recombinants or, more likely, nonpenetrant individuals. The four individuals from family 67 caused the maximum lod score to occur at a $\theta=0.13$, rather than at zero with marker D12S85.

Significantly, no individual diagnosed as affected from any of these families shows an unaffected (normal) haplotype. Diagnoses in our non9q3-linked families were often difficult, perhaps because of lower penetrance or expressivity of the ORW2 locus compared with ORW1. However, only those individuals meeting the previously defined stringent diagnostic criteria were assigned an affected phenotype. From our observations we believe there also may be a delayed age of onset of symptoms in ORW2, but the limited data do not justify gross revision of the age-dependent penetrance model used previously. Nonetheless, when the model was changed from maximum penetrance of $97 \%$ to $75 \%$ (age 40 and above), evidence for linkage of ORW2 to the three most closely linked markers remained strong (Table 2).

\section{DISCUSSION}

These data provide strong evidence for the existence of an ORW locus mapping to chromosome 12. The centromere has been localized on the physical map between markers D12S59 and D12S85 (Kucherlapati et al. 1994). Based on a comparison of physical and genetic maps, D12S59 is located within the interval between D12S345 and D12S85, an area contained within 


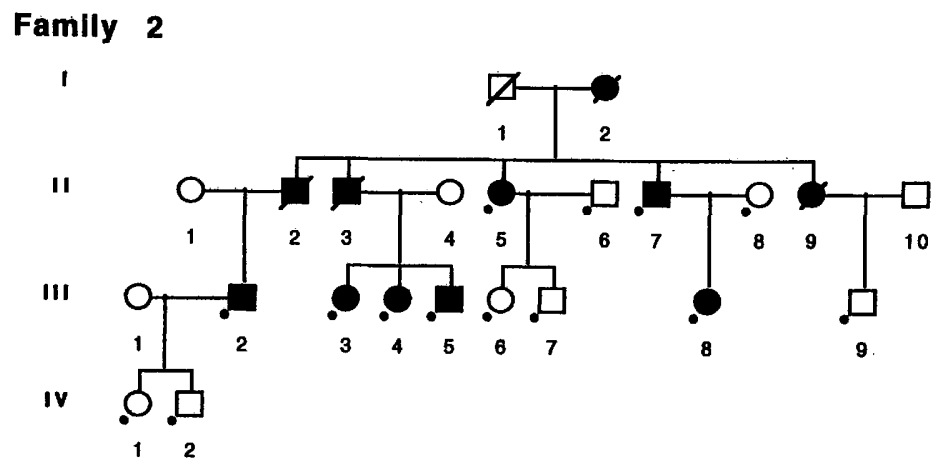

Family 17

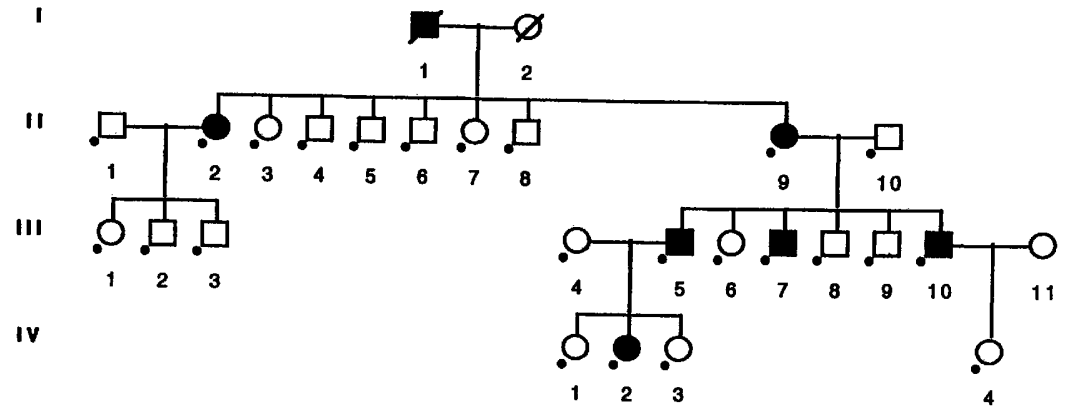

Family 33

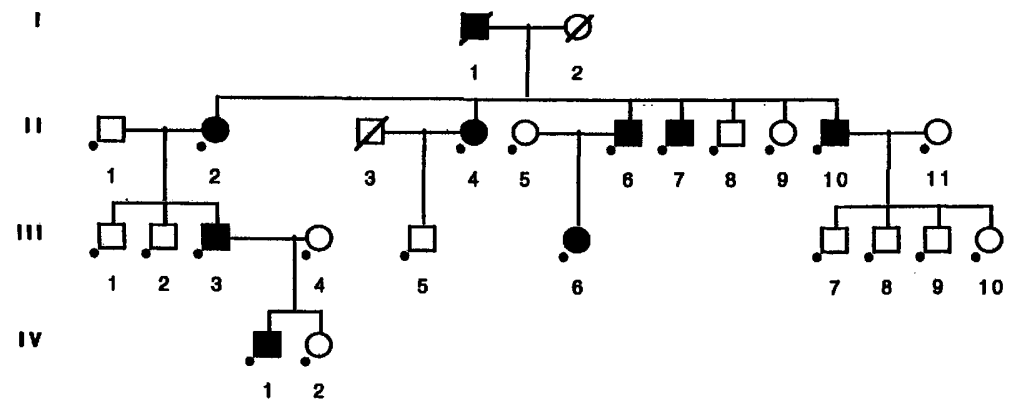

Famlly 67

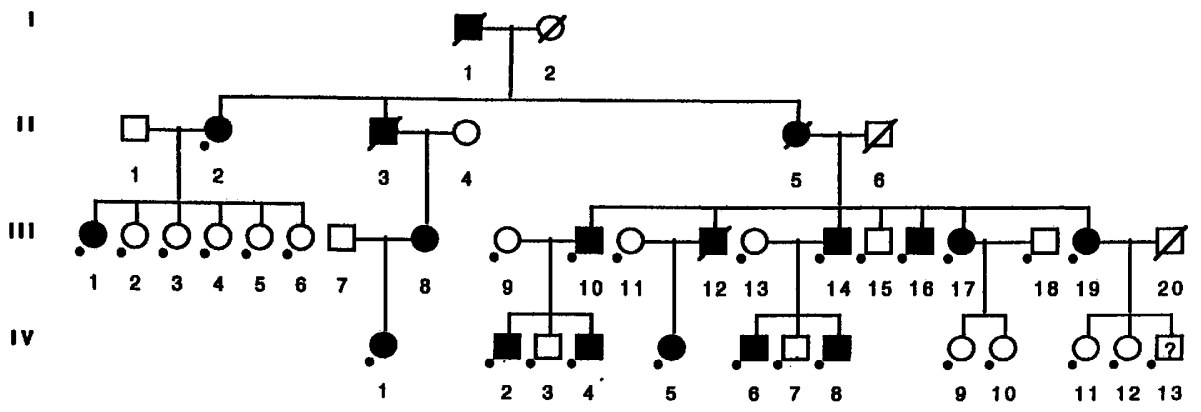

Figure 1 Pedigree drawings of the four ORW families, using standard symbols. A dot below a symbol indicates an individual who was sampled for this study. the candidate region for ORW2. Therefore, we provisionally assign the ORW2 locus as pericentromeric, as our data do not allow definitive assignment to a particular arm of chromosome 12.

Previously, we had suggested the possibility of an ORW locus mapping to chromosome 3p22 (McAllister et al. 1994b), based on a two-point lod score of 1.43 in family 33 with marker D3S1211. This marker maps near the TGF- $\beta$ receptor II, which was considered a candidate for this locus. The stronger statistical support for linkage of the disease locus in family 33 to chromosome 12 (lod score of 2.64 at $\theta=0$ for marker D12S85, Table 1) suggests that the actual location for the ORW locus in this family is the pericentromeric region of chromosome 12 . No additional families have shown linkage to this region of chromosome 3 . Thus, we have no evidence for an ORW locus mapping to 3p22. Likewise we have no evidence for other ORW loci, as we have no families that exclude both the ORW1 locus on $9 \mathrm{q}$ and the ORW2 locus on chromosome 12.

The absence of PAVMs in ORW family 67 (first described in this report) supports the previously published observation of a 
JOHNSON ET AL.

Table 1. Pairwise lod scores between HHT and chromosome 12 marker loci

\begin{tabular}{|c|c|c|c|c|c|c|c|c|c|}
\hline & & LOD sc & (Z) at & ferent & ombir & frac & & & \\
\hline Locus & Family & 0.01 & 0.05 & 0.10 & 0.20 & 0.30 & 0.40 & $Z \max$ & $\boldsymbol{\theta}$ \\
\hline D12S310 & 2 & -0.90 & -0.55 & -0.33 & -0.13 & -0.06 & -0.02 & -0.02 & 0.40 \\
\hline & 17 & 2.12 & 1.97 & 1.77 & 1.35 & 0.88 & 0.37 & 2.15 & 0.00 \\
\hline & 33 & -1.59 & -0.37 & 0.01 & 0.18 & 0.12 & 0.03 & 0.18 & 0.20 \\
\hline & 67 & -1.18 & -0.38 & 0.01 & 0.29 & 0.28 & 0.15 & 0.31 & 0.24 \\
\hline & Total & -1.55 & 0.66 & 1.46 & 1.70 & 1.23 & 0.53 & 1.74 & 0.17 \\
\hline D12S333 & 2 & -1.10 & -0.46 & -0.24 & -0.09 & -0.04 & -0.02 & -0.02 & 0.40 \\
\hline & 17 & 3.88 & 3.65 & 3.33 & 2.59 & 1.71 & 0.69 & 3.94 & 0.00 \\
\hline & 33 & 0.63 & 0.81 & 0.86 & 0.76 & 0.52 & 0.22 & 0.86 & 0.10 \\
\hline & 67 & -2.92 & -0.76 & 0.05 & 0.49 & 0.37 & 0.05 & 0.50 & 0.22 \\
\hline & Total & 0.50 & 3.24 & 4.00 & 3.75 & 2.55 & 0.94 & 4.08 & 0.13 \\
\hline D12S345 & 2 & -0.97 & 0.22 & 0.56 & 0.63 & 0.43 & 0.14 & 0.65 & 0.16 \\
\hline & 17 & 3.55 & 3.30 & 2.96 & 2.24 & 1.43 & 0.56 & 3.61 & 0.00 \\
\hline & 33 & 1.20 & 1.36 & 1.37 & 1.15 & 0.74 & 0.27 & 1.38 & 0.08 \\
\hline & 67 & -2.09 & 0.27 & 1.16 & 1.59 & 1.31 & 0.66 & 1.59 & 0.20 \\
\hline & Total & 1.69 & 5.15 & 6.06 & 5.61 & 3.91 & 1.63 & 6.13 & 0.12 \\
\hline D12S85 & 2 & 1.48 & 1.33 & 1.14 & 0.78 & 0.43 & 0.13 & 1.51 & 0.00 \\
\hline & 17 & 4.24 & 3.96 & 3.59 & 2.77 & 1.82 & 0.74 & 4.31 & 0.00 \\
\hline & 33 & 2.60 & 2.44 & 2.22 & 1.70 & 1.08 & 0.39 & 2.64 & 0.00 \\
\hline & 67 & 0.71 & 0.93 & 1.02 & 0.97 & 0.75 & 0.42 & 1.02 & 0.13 \\
\hline & Total & 9.02 & 8.66 & 7.98 & 6.22 & 4.08 & 1.69 & 9.06 & 0.00 \\
\hline D12S339 & 2 & 2.16 & 1.97 & 1.73 & 1.22 & 0.70 & 0.23 & 2.21 & 0.00 \\
\hline & 17 & 3.88 & 3.65 & 3.33 & 2.59 & 1.71 & 0.69 & 3.94 & 0.00 \\
\hline & 33 & 0.60 & 1.16 & 1.27 & 1.10 & 0.72 & 0.26 & 1.27 & 0.10 \\
\hline & 67 & 3.75 & 3.94 & 3.84 & 3.18 & 2.21 & 1.02 & 3.94 & 0.05 \\
\hline & Total & 10.39 & 10.73 & 10.16 & 8.09 & 5.34 & 2.20 & 10.77 & 0.04 \\
\hline D12S368 & 2 & 1.98 & 1.81 & 1.59 & 1.12 & 0.64 & 0.21 & 2.02 & 0.00 \\
\hline & 17 & 2.35 & 2.42 & 2.32 & 1.88 & 1.24 & 0.47 & 2.42 & 0.04 \\
\hline & 33 & 1.15 & 1.66 & 1.70 & 1.41 & 0.91 & 0.33 & 1.71 & 0.08 \\
\hline & 67 & -0.70 & -0.20 & 0.07 & 0.21 & 0.17 & 0.07 & 0.21 & 0.21 \\
\hline & Total & 4.78 & 5.69 & 5.68 & 4.63 & 2.96 & 1.07 & 5.75 & 0.07 \\
\hline D12S359 & 2 & 0.35 & 0.86 & 0.92 & 0.74 & 0.43 & 0.11 & 0.92 & 0.09 \\
\hline & 17 & 2.35 & 2.42 & 2.32 & 1.88 & 1.24 & 0.46 & 2.42 & 0.04 \\
\hline & 33 & -1.18 & -0.53 & -0.28 & -0.07 & 0.02 & 0.05 & 0.05 & 0.40 \\
\hline & 67 & 1.37 & 1.94 & 2.14 & 1.94 & 1.35 & 0.51 & 2.15 & 0.11 \\
\hline & Total & 2.89 & 4.69 & 5.11 & 4.49 & 3.03 & 1.13 & 5.11 & 0.11 \\
\hline D12S355 & 2 & 0.30 & 0.81 & 0.88 & 0.70 & 0.40 & 0.12 & 0.88 & 0.09 \\
\hline & 17 & 2.16 & 2.24 & 2.16 & 1.75 & 1.15 & 0.42 & 2.24 & 0.05 \\
\hline & 33 & 0.81 & 1.34 & 1.41 & 1.18 & 0.76 & 0.28 & 1.41 & 0.09 \\
\hline & 67 & 3.21 & 3.49 & 3.48 & 2.99 & 2.14 & 1.04 & 3.52 & 0.07 \\
\hline & Total & 6.48 & 7.88 & 7.93 & 6.63 & 4.46 & 1.85 & 8.00 & 0.08 \\
\hline
\end{tabular}

Age-dependent penetrance of HHT was estimated using the following three liability classes: ages 0-20 (penetrance 0.2425); ages 21-40 (penetrance 0.7275 ); ages $>40$ (penetrance 0.9700 ).

much reduced incidence of PAVMs in other nonORW1 families (Heutink et al. 1994; McAllister et al. 1994a; Porteous et al. 1994). Additional ORW1 and ORW2 families must be studied before accurate risk levels for the development of PAVMs can be calculated.

With the establishment of a second locus for
ORW on chromosome 12, further studies are now justified comparing both the incidence and severity of the clinical features between ORW1 and ORW2 families. These might provide vital information resulting in more accurate counseling for disease prognosis and more effective management of affected individuals. 
SECOND LOCUS FOR HHT MAPS TO CHROMOSOME 12

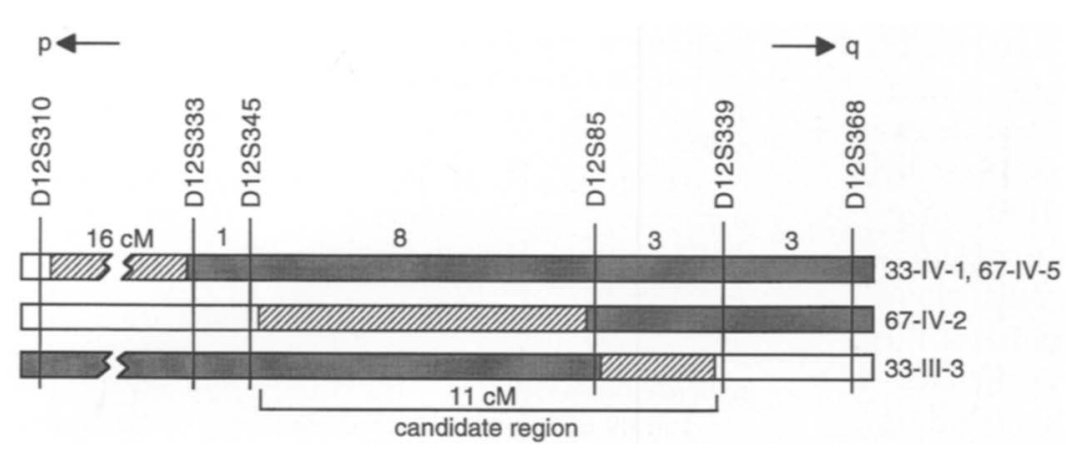

Figure 2 Graphic representation of the recombinant chromosomes identified in ORW families that define the candidate interval. The hatched boxes represent the minimum region where each recombination occurred, and the dark boxes represent the chromosome 12 region that segregates with the disease. The individuals harboring the recombinants are indicated by a code consisting of the family number, the generation number and, finally, the person number, each of which corresponds to Fig. 1. Map distances are based on Gyapay et al. (1994). The centromere is located between D12S345 and D12S85, based on a comparison of genetic and physical maps.

The identification of endoglin as the gene mutated in ORW1 (McAllister et al. 1994b) indicates the importance of TGF- $\beta$ signaling pathways in the pathology of this form of the disease. The ORW2 gene may encode an endothelial cell receptor involved in a similar process of cell signaling. Two potential candidate genes, ACVRLK1 and ACVRLK4 (activin receptorlike kinases), map to chromosome 12q11-q14 based on hybridization to a chromosome 12 hybrid mapping panel (Kucherlapati et al. 1994). ACVRLK1 (ALK1) encodes a putative cell-surface receptor with a serine/threonine kinase domain, expressed predominantly from endothelial cells (Attisano et al. 1993). It can associate with the type II TGF- $\beta$ receptor after overexpression in COS cells, although its ligand in vivo remains unknown (ten Dijke et al. 1994). ACVRLK4 (ALK4 or SKR2) encodes a ubiquitously expressed cell-surface receptor with a serine/threonine kinase domain (ten Dijke et al. 1993) that binds the growth factor activin (ten Dijke et al. 1994). Growth of vascular endothelial cells in culture is inhibited by activin- $A$ and TGF- $\beta$ causes an additive inhibitory effect (McCarthy and Bicknell 1993).

A third candidate gene that is under consideration is ITGA5, encoding the integrin $\alpha 5$ subunit, which together with the integrin $\beta 1$ subunit forms the fibronectin receptor. The ITGA5 locus

Table 2. Pairwise lod scores between HHT and chromosome 12 marker loci, using a revised penetrance model

\begin{tabular}{lccccccccc}
\hline Locus & \multicolumn{8}{c}{ Lod scores (Z) at different recombination fractions $(\boldsymbol{\theta})$} \\
Damily & $\mathbf{0 . 0 1}$ & $\mathbf{0 . 0 5}$ & $\mathbf{0 . 1 0}$ & $\mathbf{0 . 2 0}$ & $\mathbf{0 . 3 0}$ & $\mathbf{0 . 4 0}$ & Zmax & $\boldsymbol{\theta}$ \\
\hline D125345 & 2 & -1.22 & -0.01 & 0.35 & 0.46 & 0.31 & 0.09 & 0.47 & 0.17 \\
& 17 & 2.97 & 2.74 & 2.45 & 1.81 & 1.12 & 0.43 & 3.03 & 0.00 \\
& 33 & 1.76 & 1.68 & 1.55 & 1.19 & 0.74 & 0.26 & 1.78 & 0.00 \\
& 67 & -1.21 & 0.60 & 1.22 & 1.44 & 1.12 & 0.54 & 1.45 & 0.18 \\
& Total & 2.30 & 5.01 & 5.57 & 4.90 & 3.29 & 1.31 & 5.57 & 0.11 \\
D12585 & 2 & 1.24 & 1.10 & 0.93 & 0.61 & 0.32 & 0.09 & 1.27 & 0.00 \\
& 17 & 3.41 & 3.17 & 2.86 & 2.16 & 1.37 & 0.53 & 3.47 & 0.00 \\
& 33 & 2.35 & 2.21 & 2.00 & 1.52 & 0.95 & 0.34 & 2.38 & 0.00 \\
& 67 & 1.22 & 1.20 & 1.14 & 0.97 & 0.71 & 0.38 & 1.23 & 0.00 \\
& Total & 8.22 & 7.68 & 6.93 & 5.26 & 3.34 & 1.34 & 8.35 & 0.00 \\
D125339 & 2 & 1.91 & 1.74 & 1.51 & 1.04 & 1.57 & 0.17 & 1.96 & 0.00 \\
& 17 & 3.05 & 2.86 & 2.59 & 1.98 & 1.26 & 0.47 & 3.10 & 0.00 \\
& 33 & 0.35 & 0.93 & 1.05 & 0.92 & 0.59 & 0.22 & 1.05 & 0.11 \\
& 67 & 4.54 & 4.27 & 3.89 & 3.03 & 2.02 & 0.09 & 4.60 & 0.00 \\
& Total & 9.86 & 9.79 & 9.04 & 6.97 & 4.45 & 1.76 & 9.98 & 0.02 \\
\hline
\end{tabular}

Age-dependent penetrance of HHT was estimated using the following three liability classes: ages 0-20 (penetrance 0.2425); ages 21-40 (penetrance 0.7275); ages $>40$ (penetrance 0.7500 ). 


\section{JOHNSON ET AL.}

has been mapped cytogenetically to $12 \mathrm{q} 11-\mathrm{q} 13$ (Sosnoski et al. 1988). Integrin $\alpha 5$ is expressed in cell types including endothelial cells, and its expression in endothelial cells is modulated by TGF- $\beta$ (Enenstein et al. 1992). The $\alpha 5 \beta 1$ fibronectin receptor can be detected at the site of intercellular contact between endothelial cells where it regulates the integrity and permeability of the monolayer (Lampugnani et al. 1991). In addition, extracellular matrix components, including fibronectin mediate complex changes in the migratory behavior of endothelial cells (Hauser et al. 1993).

\section{METHODS}

\section{Clinical Evaluation}

Family members were interviewed and examined by a medical geneticist. The interview included relevant medical history information such as age of onset and pattern of any epistaxis, evidence for the presence of pulmonary or cerebral arteriovenous malformations, and history of gastrointestinal or pulmonary bleeding. Pertinent medical records, including chest angiography, were obtained and reviewed when available. Individuals presenting with dyspnea or cyanosis were referred for radiological examination for PAVMs. Family history was reviewed. Physical examination included a search for telangiectases on the lips, tongue, oral or nasal mucosa, cheeks, fingers, or elsewhere. Affected status was assigned based on the presence of at least two of the following three criteria: telangiectasia, recurrent epistaxis, and an affected first-degree relative (McAllister et al. 1994a; McDonald et al. 1994). Informed consent was obtained and blood samples were drawn for DNA extraction, using standard methods.

\section{Family Description}

Four families (Fig. 1) for which linkage to the ORW1 locus was excluded, were included in this study; family 2 (Porteous et al. 1994), families 17 and 33 (McAllister et al. 1994a), and family 67 (D.W. Johnson and D.A. Marchuk, unpubl.). There were no affected individuals with clinical evidence for PAVMs, despite attempts at uncovering potentially undiagnosed lesions. It appeared that the age of onset of symptoms in these families was later than in the 9q-linked families described previously (McAllister et al. 1994a; McDonald et al. 1994). No other clear clinical distinctions could be made between these and the previously described ORW1 families.

Family 2 consists of 14 sampled individuals including 7 affected members (Porteous et al. 1994). There was a wide range of severity of epistaxes and telangiectases among affected individuals. Pulse oximetry and chest $\mathrm{X}$-ray showed no evidence of PAVMs. The pedigree drawings for this and the following families are shown in Figure 1.

Family 17 consists of 24 sampled individuals, includ- ing 6 affected members (McAllister et al. 1994a). Frequent epistaxis and telangiectases are also prevalent in this family. No family member has ever been diagnosed with a PAVM.

Family 33 consists of 22 sampled individuals with 8 affected members (McAllister et al. 1994a). Symptoms in the majority of affected members include epistaxis and mucocutaneous telangiectases. One affected individual was diagnosed as having a cerebral AVM, and one member died of hepatic failure. No affected individuals had any evidence of PAVMs.

Family 67 is a new kindred consisting of 30 sampled individuals with 13 affected members. Epistaxis and mucocutaneous telangiectases are the common clinical features seen. One affected individual had a cerebral hemorrhage, and one had a history of gastrointestinal hemorrhage. Again, no affected individual had any evidence of PAVMs.

\section{Genotyping and Linkage Analysis}

Analyses of simple sequence repeat markers was performed as described previously (McDonald et al. 1994). Two-point linkage analysis was also performed as described previously (McAllister et al. 1994a). Briefly, ORW was analyzed as an autosomal dominant disorder with age-dependent penetrance. For estimating the age-dependent penetrance, three liability classes were created with age ranges $0-20$ (penetrance 0.2425$), 21-40(0.7275)$, and $>40(0.9700)$. For the data presented in Table 2, penetrance for the final age group was set at 0.7500 . Disease frequency was set at 0.0001 . Two-point linkage analysis was performed on a Sun Sparc station 10 using the MLINK subprogram of the LINKAGE computer package (v. 4.9; Lathrop et al. 1984). Allele frequency estimates for the markers were obtained from Genome Data Base.

\section{NOTE ADDED IN PROOF}

While this manuscript was under review a separate report of linkage of an HHT locus to chromosome 12 was published (Vincent et al. 1995. Hum. Molec. Genet. 4: 945949).

\section{ACKNOWLEDGMENTS}

We gratefully acknowledge the family members who participated in this study, as well as the enthusiastic support of the Hereditary Hemorrhagic Telangiectasia Foundation, International. We thank Dr. Robert I. White (Yale University Medical School) for alerting us to family 67, and Michele Walsh of the General Clinical Research Center, University of Michigan Medical School, for cell immortalization. This study was supported by National Institutes of Health (grant HL 49171) and a Baxter Foundation award to D.A.M.

The publication costs of this article were defrayed in part by payment of page charges. This article must therefore be hereby marked "advertisement" in accordance with 18 USC section 1734 solely to indicate this fact. 


\section{SECOND LOCUS FOR HHT MAPS TO CHROMOSOME 12}

\section{REFERENCES}

Aassar, O.S., C.M. Friedman, and R.I. White Jr. 1991. The natural history of epistaxis in hereditary hemorrhagic telangiectasia. Laryngoscope 101: 977-980.

Attisano, L., J. Carcamo, F. Ventura, F.M.B. Weis, J. Massague, and J.L. Wrana. 1993. Identification of human activin and TGF- $\beta$ type I receptors that form heteromeric kinase complexes with type II receptors. Cell 75: $671-680$.

Brant, A.M., A.P. Schachat, and R.I. White. 1989. Ocular manifestations in hereditary hemorrhagic telangiectasia (Rendu-Osler-Weber disease). Am. J. Ophthalmol. 107: 642-646.

Dines, D.E., R.A. Arms, P.E. Bernatz, and M.R. Gomes. 1974. Pulmonary arteriovenous fistulas. Mayo Clin. Proc. 49: $460-465$.

Enenstein, J., N.S. Waleh, and R.H. Kramer. 1992. Basic FGF and TGF-beta differentially modulate integrin expression of human microvascular endothelial cells. Exp. Cell Res. 203: 499-503.

Gyapay, G., J. Morissette, A. Vignal, C. Dib, C. Fizames, P. Millasseau, S. Marc, G. Bernardi, M. Lathrop, and J. Weissenbach. 1994. The 1993-94 Genethon human genetic linkage map. Nature Genet. 7: 246-339.

Hauser, I.A., E. Setter, L. Bell, and J.A. Madri. 1993. Fibronectin expression correlates with U937 cell adhesion to migrating bovine aortic endothelial cells in vitro. Am. J. Pathol. 143: 173-180.

Heutink, P., T. Haitjema, G.J. Breedveld, B. Janssen, L.A. Sandkuijl, C.J.M. Bontekoe, C.J.J. Westerman, and B. Oostra. 1994. Linkage of hereditary hemorrhagic telangiectasia to chromosome $9 \mathrm{q} 34$ and evidence for locus heterogeneity. J. Med. Genet. 31: 933-936.

Kucherlapati, R., I. Craig, and P. Marynen. 1994. Report of the second international workshop on human chromosome 12 mapping 1994. Cytogenet. Cell Genet. 67: 246-264.

Lampugnani, M.G., M. Resnati, E. Dejana, and P.C. Marchisio. 1991. The role of integrins in the maintenance of endothelial monolayer integrity. J. Cell Biol. 112: $479-490$.

Lathrop, G.M., J.M. Lalouel, C. Julier, and J. Ott. 1984. Strategies for multilocus linkage analysis in humans. Proc. Natl. Acad. Sci. 81: 3443-3446.

McAllister, K.A., F. Lennon, B. Bowles-Biesecker, W.C. McKinnon, E.A. Helmbold, D.S. Markel, C.E. Jackson, A.E. Guttmacher, M.A. Pericak-Vance, and D.A. Marchuk. 1994a. Genetic heterogeneity in hereditary hemorrhagic telangiectasia: Possible correlation with clinical phenotype. J. Med. Genet. 31: 927-932.

McAllister, K.A., K.M. Grogg, D.W. Johnson, C.J. Gallione, M.A. Baldwin, C.E. Jackson, E.A. Helmbold,
D.S. Markel, W.C. McKinnon, J. Murrell, M.K. McCormick, M.A. Pericak-Vance, B.A. Oostra, T. Haitjema, C.J.J. Westerman, M.E. Porteous, A.E. Guttmacher, M. Letarte, and D.A. Marchuk. 1994b. Endoglin, a TGF- $\beta$ binding protein of endothelial cells, is the gene for hereditary haemorrhagic telangiectasia type 1. Nature Genet. 8: 345-351.

McCarthy, S.A., and R.Bicknell. 1993. Inhibition of vascular endothelial cell growth by activin-A.J. Biol. Chem. 268: 23066-23071.

McDonald, M.T., K.A. Papenberg, S. Ghosh, A.A. Glatfelter, B.B. Biesecker, E.A. Helmbold, D.S. Markel, A. Zolotor, W.C. McKinnon, J.L. Vanderstoep, C.E. Jackson, M. Iannuzzi, F.S. Collins, M. Boehnke, M.E. Porteous, A.E. Guttmacher, and D.A. Marchuk. 1994. A disease locus for hereditary haemorrhagic telangiectasia maps to chromosome 9q33-34. Nature Genet. 6: 197-204.

Peery, W.H. 1987. Clinical spectrum of hereditary hemorrhagic telangiectasia (Osler-Weber-Rendu disease). Am. J. Medicine 82: 989-996.

Plauchu, H., J.-P. Chadarevian, A. Bideau, and J.-M. Robert. 1989. Age-related clinical profile of hereditary hemorrhagic telangiectasia in an epidemiologically recruited population. Am. J. Med. Genet. 32: 291-297.

Porteous, M.E.M., J. Burn, and S.J. Proctor. 1992. Hereditary haemorrhagic telangiectasia: A clinical analysis. J. Med. Genet. 29: 527-530.

Porteous, M.E.M., A. Curtis, O. Williams, D. Marchuk, S.S. Bhattacharya, and J. Burn. 1994. Genetic heterogeneity in hereditary haemorrhagic telangiectasia. J. Med. Genet. 31: 925-926.

Reilly, P.J., and T.T. Nostrant. 1984. Clinical manifestations of hereditary hemorrhagic telangiectasia. Am. J. Gastroenterol. 79: 363-367.

Shovlin, C.L., J.M.B. Hughes, E.G.D. Tuddenham, I. Temperley, Y.F.N. Perembelon, J. Scott, C.E. Seidman, and J.G. Seidman. 1994. A gene for hereditary haemorrhagic telangiectasia maps to chromosome $9 \mathrm{q} 3$. Nature Genet. 6: 205-209.

Sosnoski, D., B.S. Emanuel, A.L. Hawkins, P. van Tuinen D.H. Ledbetter, R.L. Nussbaum, F.-T. Kaos, E. Schwartz, D. Phillips, J.S. Bennett, L.A. Fitzgerald, and M. Poncz. 1988. Chromosomal localization of the genes for the vitronectin and fibronectin receptors alpha-subunits and for platelet glycoproteins IIb and IIIa. J. Clin. Invest. 81: 1993-1998.

ten Dijke, P., H. Ichijo, P. Franzen, P. Schulz, J. Saras, H. Toyoshima, C.-H. Heldin, and K. Miyazono. 1993. Activin receptor-like kinases: A novel subclass of cell-surface receptors with predicted serine/threonine kinase activity. Oncogene 8: 2879-2887.

ten Dijke, P., H. Yamashita, H. Ichijo, P. Franzen, M. Laiho, K. Miyazono, and C.-H. Heldin. 1994. 


\section{JOHNSON ET AL.}

Characterization of type I receptors for transforming growth factor- $\beta$ and activin. Science 264: 101-104.

Vase, P., and O. Grove. 1986. Gastrointestinal lesions in hereditary hemorrhagic telangiectasia. Gastroenterology 91: 1079-1083.

White, R.I., and J.S. Pollak 1994. Pulmonary arteriovenous malformations: options for management. Ann. Thorac. Surg. 57: 519-521.

Willinsky, R.A., P. Lasjaunias, K. Terbrugge, and P.

Burrows. 1990. Multiple cerebral arteriovenous malformations (AVMs). Review of our experience from 203 patients with cerebral vascular lesions.

Neuroradiology 32: 207-210.

Received May 3, 1995; accepted in revised form June 15, 1995. 


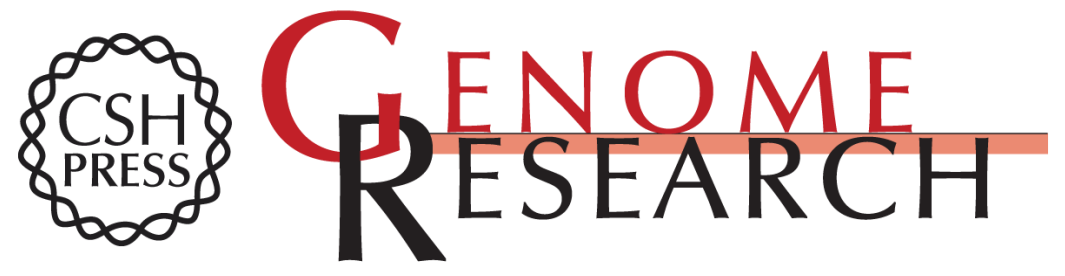

\section{A second locus for hereditary hemorrhagic telangiectasia maps to chromosome 12.}

D W Johnson, J N Berg, C J Gallione, et al.

Genome Res. 1995 5: 21-28

Access the most recent version at doi:10.1101/gr.5.1.21

References This article cites 27 articles, 8 of which can be accessed free at:

http://genome.cshlp.org/content/5/1/21.full.html\#ref-list-1

\section{License}

Email Alerting Receive free email alerts when new articles cite this article - sign up in the box at the Service top right corner of the article or click here.

\section{Affordable, Accurate Sequencing.}

To subscribe to Genome Research go to:

https://genome.cshlp.org/subscriptions 